\title{
PLURALISME DAN FUNDAMENTALISME RELIGIUS
}

Oleh: Alexander Reba

\begin{abstract}
Abstrak:
Dewasa ini, peluralisme religius dan fundamentalisme merupakan salah satu fenomena sejarah. Sebagai fenomena sejarah pluralisame religius dan fundamentalisme sedang hangat dibicarakan di seluruh dunia, termasuk Indonesia. Dalam bidang agama, fundamentalisme merupakan gerakan untuk kembali kepada apa yang diyakini sebagai dasar-dasar atau asas-asas keagamaan yang benar dan menentang membaharuan. Demikian pula pluralisme religius sebagai keadaan masyarakat majemuk ditilik dari segi agama juga merupakan kenyataan.

Namun pengaruh sikap mental ditambah klaim mayoritas dari para penganut agama sering menimbulkan bentrok atau konflik sosial. Karena itu, dengan dasar negara Pancasila, setiap kelompok agama dihimbau agar dalam menjalankan agamanya tidak saja mengagungkan Tuhan (matra vertikal), melainkan juga mempunyai perhatian terhadap masalah kemanusiaan (matra horizontal). Di sini sebisa mungkin agama didorong untuk menjadi lokomotif pembebasan manusia dari segala belenggu dan penindasan yang timbul dari sesama umat beragama.
\end{abstract}

Kata-kata Kunci: pluralisme, pluralisme religius, fundamentalisme, militansi, mayoritasminoritas, konflik sosial.

\section{PLURALISME RELIGIUS}

\subsection{Apa itu Pluralisme Religius}

$\mathrm{P}$ luralisme, menurut Kamus Besar Bahasa Indonesia, adalah keadaan masyarakat yang majemuk (bersangkutan dengan sistem sosial dan politiknya). ${ }^{1}$ Berdasarkan arti kata tersebut, bila diterapkan pada pluralisme religius, maka pluralisme religius diartikan sebagai keadaan masyarakat majemuk ditilik dari segi agama. Dewasa ini, pluralisme religius merupakan kenyataan global, setiap negara di dunia hidup dalam suasana pluralisme religius. Masyarakat dalam suatu negara hidup berdampingan dengan bermacam-macam agama dan aliran kepercayaan.

Indonesia merupakan salah satu dari antara negara-negara di dunia yang plural. Pluralitas negara Indonesia bisa dilihat dari keanekaragaman ras, suku, bahasa (daerah), adat istiadat dan agama bangsa Indonesia. Kenyataan yang pluralistis ini tak dapat disangkal merupakan sebuah kekayaan. Namun, kekayaan ini jika tidak dikelola dengan baik dapat menjadi ancaman serius bagi Negara Kesatuan Republik Indonesia (NKRI) dan bisa berakibat fatal.

\subsection{Gereja Katolik dan Pluralisme}

Gereja Katolik melalui Konsili Vatikan II menunjukkan suatu keterbukaan ke segala arah. Suatu "tanda zaman" yang menunjukkan keterbukaan terhadap masyarakat modern dan pluralistis karena dokumen-dekumen yang dihasilkannya menunjukkan hal tersebut. Menyangkut sikap Gereja Katolik terhadap realitas pluralisme dapat disimak pada salah satu dokumennya, yaitu

${ }^{1}$ Depdiknas, Kamus Besar Bahasa Indonesia, Edisi Ketiga, Cetakan Kedua (Jakarta: Balai Pustaka. 2002), hlm. Op. Cit., hlm. 883 . 
pernyataan tentang hubungan Gereja dengan agama-agama bukan Kristen dalam dekrit Nostra Aetate. Dalam dokumen tersebut Konsili menyatakan antara lain:

Gereja Katolik tidak menolak apa pun, yang dalam agama-agama itu serba benar dan suci. Dengan sikap hormat yang tulus Gereja merenungkan cara-cara bertindak dan hidup, kaidah-kaidah, serta ajaran-ajaran, yang memang dalam banyak hal berbeda dari apa yang diyakini dan diajarkannya sendiri, tetapi tidak jarang toh memantulkan sinar kebenaran yang menerangi semuan orang (NA 2).

Penyataan ini mengungkapkan sebuah pengakuan rendah hati akan fakta pluralisme religius dunia. Gereja hidup, berjuang, serta berziarah dalam kondisi kemajemukan itu. Pernyataan tersebut mengungkapkan penghargaan atas keberbedaan sebagai realitas dunia. Pengakuan akan tempat agama-agama dalam sejarah karya penyelamatan Allah sama sekali tidak berarti bahwa iman sendiri berkurang. Sebaliknya, bagi Gereja Katolik fakta kemajemukan itu justru sebagai bagian dari iman kepercayaan kepada Yesus Kristus pada zaman ini. ${ }^{2}$ Ini pulalah yang dinyatakan dalam pengantar pernyataan tentang hubungan Gereja dengan agama-agama bukan Kristiani:

Di zaman kita umat manusia makin hari makin disatukan makin erat dan hubungan antara pelbagai bangsa makin meningkat. Dengan perhatian lebih besar Gereja mempertimbangkan bagaimana sikapnya terhadap agama-agama bukan kristiani. ... Karena semua bangsa merupakan satu komunitas, maka mereka mempunyai satu asal usul yang sama, sebab Allah memberikan kepada umat mausia seluruh bumi untuk dihuni (NA1).

Gereja Katolik melalui Konsili Vatikan II mengubah peta hubungan antaragama, baik pada tingkat dunia, maupun tingkat lokal; merambah pada tingkat global dan mempunyai pengaruh mendalam dalam kehidupan jemaat-jemaat lokal. Bukan hanya Gereja Katolik yang dengan gembira merujuk pada dokumen Konsili Vatikan II, akan tetapi juga dengan segenap hati agama lain menunjuk dokumen tersebut selaku sebuah milik dan pencapaian bersama. Dokumen tersebut diterima sebagai sebuah harapan, sebagai munculnya semangat baru dalam menjalankan dialog antaragama karena memandang bangsa-bangsa dunia sebagai suatu komunitas.

Menyikapi pandangan bahwa semua bangsa merupakan satu komunitas seharusnya menggerakkan hati semua pihak yang beragama untuk memerangi "politik identitas sektarian", sebaliknya membangun "dialog” sebagai komitmen bersama.

\subsection{Keharusan Dialog}

Hidup dalam suasana pluralisme religius, sering menghasilkan suatu pemikiran kreatif dan perkembangan baru dalam bidang hubungan antaragama. Artinya para pemeluk masing-masing agama berusaha mencari dan menemukan suatu format bersama untuk membangun dialog. Sekurang-kurangnya di Asia, juga kiranya di Indonesia, tujuannya yang mau dicapai dengan dialog adalah untuk membangun "komunitas yang manusiawi", di mana setiap orang hidup berdampingan dengan aman, damai dan penuh persaudaraan.

Bagi dunia dewasa ini, dan Indonesia khususnya, dialog merupakan suatu keharusan. Ada beberapa faktor yang mendasari keharusan dialog dewasa ini. ${ }^{3}$

${ }^{2}$ Bdk. I. Suharyo, The Catolic Way Kekatolikan dan Keinndonesiaan Kita (Yogyakarta: Kanisius, 2009), hlm. 77.

${ }^{3}$ Andreas Bernadinus Atawolo, Dialog Antarumat Beragama, Kerjasama Membangun Kerajan Allah, Telaah Kritris Pemikiran Jacques Dupuis (Yogyakarta: Yayasan Pustaka Nusatama), hlm. 597. 
Faktor Pertama, kenyataan bahwa di banyak tempat di bumi ini terjadi penindasan dan pemerkosaan terhadap martabat manusia karena perbedaan pendapat, keyakinan, agama dan suku. Sementara itu, kuatnya tuntutan untuk menghargai kebebasan manusia sebagai pribadi, merupakan tuntutan keharusan dialog.

Faktor kedua, ciri kesejarahan manusia. Bahwa manusia berkembang secara historis dalam ruang dan waktu, tahap demi tahap. Penghayatan kebenaran agama pun tidak luput dari perkembangan ini, yaitu bahwa perkembangan penghayatan kebenaran agama bukan sesuatu yang langsung sempurna dimiliki, melainkan harus terus dicari sejalan dengan perkembangan sejarah. Maka sikap yang paling tepat untuk mencari kebenaran adalah dialog.

Faktor ketiga adalah globalisasi. Di era globalisasai dewasa ini terjadi perjumpaan antara berbagai macam orang, kebudayaan, agama dan pandangan hidup yang berbeda-beda dari seluruh penjuru dunia. Oleh karena itu, agar kehidupan bersama dapat dipertahankan tanpa penindasan, dialog mutlak diperlukan.

Khusus untuk konteks Indonesia, dokumen Konsili Vatikan II masih sangat relevan. Setelah melewati masa-masa yang sulit dan lama, maka gagasan mengenai "inklusifisme" dianggap cukup, bahkan sangat memadai untuk masa sekarang ini. Sikap-sikap yang konfrontatif dan polemisapologetis telah digantikan dengan sikap yang lebih simpatik dan terbuka untuk dialog, yaitu inklusifisme. Pemahaman yang inklusifistik tersebut tidak berarti meninggalkan iman sendiri, melainkan justru dengan melihat hal yang positif dari iman agama lain, iman sendiri diperkaya dan diperteguh.

\subsection{Bagaimana Membangun Dialog?}

Dalam deklarasi akhir para peserta simposium sumber daya spiritual agama-agama untuk perdamaian (Roma, 16-18 Januari 2003) yang diselenggarakan oleh Dewan Kepausan untuk Dialog Antaragama, dikatakan, " Orang dapat mengatakan bahwa dewasa ini beragama berarti beragama bersama orang yang menganut agama lain". ${ }^{4}$ Maksudnya orang tidak mungkin beragama di bawah kungkungan "tempurung"-nya sendiri. Realitas demikian yang perlu dibangun adalah dialog. Berdasarkan pengalaman yang sudah berjalan, dialog yang diupayakan ${ }^{5}$ adalah:

Pertama, dialog kehidupan. Dialog kehidupan ini mencakup segala bentuk pergaulan dan hubungan sosial antara penganut-penganut agama yang berbeda. Dialog seperti itu terjadi dalam keluarga, masyarakat, dan dalam berbagai bidang kerja, seperti pendidikan, kesenian, ekonomi, politik. Masing-masing pribadi menghayagi hidup dan/atau pekerjaannya berdasarkan keyakinan imannya sendiri, dalam kebersamaan hidup dan/atau pekerjaan tanpa memusatkan perhatian pada keyakinan iman yang berbeda.

Kedua, dialog karya. Dialog ini berupa kerja sama dengan orang yang berkeyakinan iman lain untuk tujuan kemanusiaan, sosial, ekonomi, atau politik demi pembebasan atau kemajuan masyarakat.

\footnotetext{
${ }^{4}$ Dikutip dalam I. Suharyo, Op.Cit. hlm. 82.

5 Ibid., hlm. 83-84.
} 
Ketiga, dialog pakar. Dialog ini terjadi pada tataran keahlian, baik untuk memperdalam dan memperkaya warisan religius masing-masing maupun untuk menerapkan keahlian masing-masing pada masalah-masalah yang harus dihadapi umat manusia sepanjang sejarah.

Keempat, dialog pengalaman religius. Dialog jenis ini, orang-orang yang berakar dalam tradisi keagamaan masing-masing dapat berbagi pengalaman mereka dalam doa, kontemplasi, iman dan kewajiban, dan juga ungkapan serta jalan mencari Yang Mutlak. Dialog ini menjadi wadah untuk saling memperkaya dan bekerja sama dengan baik untuk memperkaya dan memelihara nilai-nilai tertinggi dan cita-cita rohani. Jadi dialog sesungguhnya mencakup semua hubungan antaragama yang positif dan konstruktif dengan orang peorangan dan komunitas lain yang ditujukan untuk saling mengerti dan saling memperkaya.

Justru hal inilah tantangan serius bagi Indonesia dewasa ini, yaitu dialog atarumat beragama. Tantangan ini muncul manakala perbedaan-perbedaan keyakinan yang fundamental menciptakan, atau digunakan untuk menciptakan, ketegangan-ketegangan dalam keluarga atau komunitas, yang secara kasat mata tampak tak terelakkan. ${ }^{6}$ Di Indonesia tantangan ini tampil dalam bentuk fundamentalisme religius, yang sering mengarah kepada radikalisme. Apa dan bagaimana munculnya fundamentalisme religius secara sederhana dapat diikuti dalam uraian berikut.

\section{FUNDAMENTALISME RELIGIUS}

\subsection{Apa itu Fundamentalisme}

Fundamentalisme berasal dari kata dasar fundamen, yang berarti 1) "asas, dasar atau hakikat" atau 2) "alas, dasar, fondasi". ${ }^{7}$ Fundamentalisme merupakan kata bentukan dari kata sifat "fundamental", dan imbuhan "isme". Dalam Bahasa Indonesia, imbuhan "isme" memiliki arti "aliran" atau "paham". Berdasarkan arti kata tersebut, fundamentalisme adalah paham atau aliran yang cenderung untuk memperjuangkan sesuatu secara radikal. ${ }^{8}$

Fundamentalisme merupakan salah satu fenomena sejarah. Sebagai fenomena sejarah fundamentalisme mempunyai latar belakang beragam, baik latar belakang teologis-keagamaan maupun politis. Dewasa ini fundamentalisme sedang hangat dibicarakan di seluruh dunia, termasuk Indonesia. Dalam bidang agama, fundamentalisme dapat didefinisikan sebagai gerakan dalam sebuah aliran atau paham keagamaan yang berupaya untuk kembali kepada apa yang diyakini sebagai dasar-dasar atau asas-asas keagamaan yang benar. Dalam pengertian ini, fundamentalisme bertujuan mempertahankan ajaran-ajaran lama (tradisional) dan menentang membaharuan. ${ }^{9}$

${ }^{6}$ Tore Lindholm, Cs. Kebebasan Beragama atau Berkeyakinan: Seberapa Jauh? Sebuah Referensi tentang Prinsip-Prinsip dan Praktek. Rafael Edy Bosko dan M. Rifa'i Abduh (Penerj.) (Yogyakarta: Kanisius, 2010$)$, hlm. 1.

${ }^{7}$ Depdiknas, Op. Cit., 322.

${ }^{8}$ Ibid.

${ }^{9}$ Amir Mugozin, https://medium.com/@mugozin76/fenomena-fundamentalisme-dan-radikalisme 


\subsection{Ciri Corak Fundamentalisme}

Martin Marty dan Scott R. Applebly seperti yang dikutip dalam B. Bevans, ${ }^{10}$ mengatakan fundamentalisme ada hampir di setiap aliran kepercayaan. Namun tidak ada satu bentuk fundamentalisme yang seragam. Karena itu Marty dan Appleby tidak membuat suatu definisi tentang fundamentalisme, melainkan keduanya membuat suatu daftar beberapa ciri khas yang menjadi corak semua fundamentalisme.

1. Marty dan Appleby merujuk kepada militansi yang menandai setiap jenis fundamentalisme. Menurut keduanya, kaum fundamentalis berjuang menentang apa yang mereka anggap relativisme kemodernan. Dalam memperjuangkan tujuan yang mau dicapai kaum fundamentalis menggunakan sarana-sarana modern, namun mereka bukan kaum modernis. Mereka justru melihat dunia modern sebagai yang jahat, rusak, durhaka. ${ }^{11}$

2. Kaum fundamentalis berjuang untuk visi hidup tertentu atau agama, atau liturgi, atau pemerintah, yang sering diyakini lebih tua, tradisional atau asli.

3. Mereka berjuang dengan "khazanah sumber daya yang dipilih secara khusus yang dianggap bisa menjadi senjatanya". Sumber tersebut bisa jadi Alkitab Kristen, Al-Quran Islam, atau Misa Tridentina dari kaum Katolik ultra-konservatif.

4. Mereka berjuang memerangi orang-orang yang tidak turut serta dalam keyakinan mereka, entah kafir, penganjur ide-ide liberal, atau orang-orang yang mencari kompromi atau dialog, baik dalam kelompok sendiri maupun diluarnya.

5. Mereka adalah sectarian, dalam pengertaian terpisah dari orang-orang lain, merasa diri mereka berada di atas orang-orang lain.

6. Akhirnya mereka beprinsip bahwa mereka berjuang di bawah Allah, atau atas nama nilai transenden tertentu. Dengan kata lain, perjuangan mereka diabsahkan yang ilahi dan dimandati yang ilahi, dan karenanya tidak ada persoalan menyangkut kebenaran mereka.

\subsection{Agama dan Fundamentalisme}

Manusia adalah makhluk religius, homo religiosus. ${ }^{12}$ Pernyataan ini hendak menampilkan suatu kebenaran bahwa manusia siapa pun dia adalah orang beragama. Agama menjadi identitas kemanusiaan manusia. Homo religiosus adalah sebutan untuk manusia dalam kualitasnya sebagai makhluk percaya, yang tidak mungkin hidup tanpa meyakini sesuatu sama sekali. Bisakah kita meniadakan keyakinan? Bahkan ketika manusia menolak untuk meyakini agama, ideologi, atau mazhab tertentu, saat itu dia sedang membuat keyakinan baru. Oleh karena itu, menolak untuk percaya sama sekali dapat kita sebut contradictio in terminis (kontradiksi dalam kata), dan bukan dalam realitas. Dalam realitas, manusia merupakan makhluk yang tidak bisa hidup dengan

${ }^{10}$ Stephen B. Bevans, Teologi dalam Perspektif Global, sebuah Pengantar (Maumere: Penerbit Ledalero, 2010), 279.

${ }^{11}$ Ibid.

12 Istilah homo religiosus dipopuletkan oleh Mircea Eliade. Menurut Eliade, homo religiosus adalah tipe manusia yang hidup dalam suatu alam yang sakral, penuh dengan nilai-nilai keagamaan dan dapat menikmati kesucian yang ada dan tampak pada alam semesta, alam materi, tumbuhan, hewan, dan manusia. Pengalaman dan penghayatan akan Yang Suci ini selanjutnya ikut menentukan corak serta cara hidupnya. Oleh Eliade, homo religiosus ini dipertentangkan dengan homo non-religiosus, yaitu manusia tidak beragama, manusia modern yang hidup di alam yang sudah didesakralisasikan, bulat-bulat alamiah, apa adanya, tanpa sakralitas yang dirasa atau dialami. 
ketidakpastian sama sekali. Asumsi fundamental yang dijadikan alasan adalah agama merupakan semangat manusia (religion is human spirit). Manusia hidup tidak pernah lepas dari agama. ${ }^{13}$ Agama diyakini mengemban fungsi memupuk persaudaraan sejati antarumat manusia. Kendati fungsi tersebut telah dibuktikan dengan fakta-fakta konkret dari zaman ke zaman, namun di samping fakta yang positif itu, dalam sepak terjang atau tingkah laku penghayatan kehidupan keagamaan terdapat pula fakta negatif, yaitu fakta perpecahan (konflik sosial) antarumat manusia yang, antara lain, bersumber pada agama. ${ }^{14}$ Namun, istilah fundamentalisme sendiri berasal dari dunia agama, khususnya dari teologi. ${ }^{15}$ Ada beberapa bentuk konflik sosial yang bersumber dari agama seperti: 1) perbedaan doktrin dan sikap mental; 2) Perbedaan suku dan ras umat beragama; 3) Perbedaan tingkat kebudayaan; serta 4) Masalah mayoritas dan minoritas pemeluk agama. ${ }^{16}$ Namun, dewasa ini fundamentalisme yang cukup menonjol disebabkan oleh: 1) Perbedaan doktrin dan sikap mental; serta 2) Masalah mayoritas dan minoritas pemeluk agama.

\subsubsection{Perbedaan doktrin dan sikap mental}

Perbedaan doktrin dan sikap mental dari para penganut agama menimbulkan bentrok atau konflik sosial. Para pihak yang sedang terlibat dalam bentrokan menyadari bahwa justru perbedaan doktrin itulah yang menjadi penyebab utama benturan itu. Entah disadari atau tidak, masingmasing pihak mempunyai gambaran tentang ajaran agamanya. Ia lalu membandingkan ajaran agamanya dengan ajaran agama yang lain (lawan). Dalam penilaian, agama sendiri selalu dijadikan patokan kebenaran (reference group), sedangkan agama yang lain dinilai menurut patokan itu. Skala fiktifnya kurang lebih sebagai beikut: ${ }^{17}$

- Agama A (agama yang saya anut) adalah paling benar dan paling lengkap.

- Agama B (agama lawan) mempunyai unsur-unsur kebenaran (tidak lengkap).

- Agama C (agama lain) mempunyai sedikit kebenaran (amat tidak lengkap).

- Agama D adalah agama kafir (tidak punya kebenaran).

Demikian seterusnya, agama B pun tidak mau ketinggalan akan menempatkan agamanya sendiri pada jenjang paling atas dan lainnya pada tingkat paling bawah, begitu seterusnya. Skala penilaian tersebut, kendati ada dalam pikiran namun tidak jarang terungkap pula dalam kata-kata, bahkan dalam sikap terhadap agama yang lain. Bentuk bentrokan pada tingkap kognitif-evaluatif ini dikenal sejak dulu dengan istilah "apologetika". Apologetika adalah bagian dari teologi yang membela dan mempertahankan kebenaran agama yang diimaninya terhadap serangan yang datang dari dalam maupun dari pihak luar. Dalam tradisi Kristiani pembelaan demikian dikenal sejak kurang lebih abad II (melawan gnotisisme) dan memuncak pada konsili Trente (1545-1563), yaitu sikap konsili terhadap gerakan protestantisme. Prinsip yang dipegang teguh ialah bahwa bukan yang menyerang itu menang, melainkan yang benar mesti menang.

Namun, dari sekian banyak polemik yang pernah terjadi dari masa ke masa dapat disimpulkan bahwa apologi yang konfrontatif, yang bertujuan mencari menang sendiri dengan

${ }^{13}$ Ismatillah A Nuad, Fundamentalisme Progresif, era baru dunia Islam (Jakarta: Penerbit Panta Rei, 2005), hlm. 1.

${ }^{14}$ D. Hendropuspito, Sosiologi Agama (Yogyakarta: Kanisius-BPK Gunung Mulia, 1983), hlm.151.

${ }^{15}$ Tom Jacobs, Paham Allah, dalam Filsafat, Agama-Agama, dan Teologi (Yogyakarta: Kanisius, 2002), hlm. 256.

${ }^{16}$ Hendropuspito, Op.Cit., hlm. 151.

${ }^{17}$ Ibid., 152. 
mengalahkan pihak lawan, belum pernah menghasilkan buah yang positif, malah meruncingkan masalah dan membuatnya tidak kunjung berakhir.

Hal lain adalah sikap mental umat beragama. Sikap mental juga merupakan pemicu masalah konflik antargolongan beragama. Sikap mental ini nampak dalam keyakinan bahwa agamanya memiliki ajaran yang paling benar. Sikap tersebut memandang rendah pemeluk agama yang lain. Satu-satunya jalan yang dapat ditempuh ialah kembali kepada prinsip: "Kebebasan memeluk agama dan kepercayaan yang disukai dan memegang teguh asas saling menghormati antarpenganut agama dan kepercayaan".

\subsubsection{Masalah Mayoritas dan Minoritas Penganut Agama}

Fenomena konflik sosial lain yang terjadi di tengah masyarakat saat ini adalah masalah mayoritas dan minoritas penganut agama. ${ }^{18}$ Dampak hubungan mayoritas-minoritas pada tingkat internasional kurang terasa daripada di tingkat nasional. Hal ini mudah dipahami karena kepentingan yang berbeda-beda pada tempat dan saat yang sama mudah menimbulkan benturan antara golongan yang berkepentingan.

Kejadian yang tidak diinginkan ini sangat terasa di Indonesia, khususnya di daerah-daerah di mana mayoritas penduduknya menganut agama tertentu. Namun di Indonesia perselisihan diakibatkan oleh agama secara prinsip dibendung oleh dasar negara Pancasila dan landasan kontitusional UUD 1945. ${ }^{19}$ Setiap warga negara diberi kebebasan menganut agama yang dipilihnya dan diberi hak untuk melaksanakannya, baik sendiri maupun bersama-sama. Namun akibat kelemahan dan keterbatasan manusiawi, pelaksanaan tidak selalu sesuai dengan prinsipnya. Sifat negatif mayoritas sering muncul bukan hanya di bidang politik kenegaraan, tetapi juga dalam bidang keagamaan dan melahirkan fundamentalisme religius.

\subsection{Fundamentalisme Dewasa ini}

Dewasa ini, fundamentalisme terjadi berhubungan dengan berbagai fenomena yang terjadi di tengah masyarakat. Terlebih setelah kejadian pengeboman kedua menara kembar World Trade Center (WTC) pada 11 September 2001 (di New York) telah melambungkan fundamentalisme sebagai fenomen global yang menakutkan. Dugaan berat atas keterlibatan Osama bin Laden kian menegaskan bahwa fundamentalisme telah menggunakan agama sebagai justifikasi. ${ }^{20}$ Sejak saat itu fundamentalisme sering disandingkan dengan paham "radikalisme" keagamaan, bahkan juga dengan "terorisme".

Radikalisme berasal dari kata Latin "radix", yang berarti "akar", yaitu keinginan perubahan mendasar sampai ke akar-akarnya. Radikalisme, yaitu paham atau aliran yang menginginkan perubahan atau pembaharuan sosial dan politik dengan cara kekerasan atau drastis. ${ }^{21}$ Sebagai contoh, di Indonesia berkembang isu Islam radikal, yang mengandung makna kelompok Islam yang memiliki keyakinan ideologis tinggi dan fanatik yang mereka perjuangkan untuk menggantikan tatanan nilai dan sistem yang sedang berlaku dalam suatu masyarakat. Radikalisme

\footnotetext{
${ }^{18}$ Ibid. hlm. 164.

${ }^{19}$ Hendropuspito, Op. Cit., 165.

20 Zuhairi Misrawi, dalam Ismatillah A Nuad, Fundamentalisme Progresif, era baru dunia Islam (Jakarta; Penerbit Panta Rei, 2005), hlm. xvi.

${ }^{21}$ Depdiknas, Op. Cit. hlm. 919.
} 
merupakan suatu usaha sekelompok orang yang ingin mencapai tujuannya dengan menghalalkan segala cara, baik dengan jalan revolusioner atau dengan jalan ekstremisme.

Sementara fundamentalisme lebih merupakan suatu keyakinan untuk kembali pada fondasi dan dasar-dasar agama yang dianut. Dengan demikian, fundamentalisme dalam arti tertentu lebih lunak dan positif daripada radikalisme, bila dimaksudkan kembali kepada dasar atau sumbersumber asli, seperti Islam kembali kepada Al-Quran dan Sunnah. Di kalangan orang Kristen, secara historis, pernah terjadi tatkala orang Kristen di bawah Marthin Luther berlakukan Kitab Suci sebagai kebenaran tunggal menyingkirkan Tradisi Lisan warisan para Rasul, yang dikenal dengan gerakan protestantisme (Abad Ke-16). Gerakan fundamentalisme tidak saja terbatas pada bidang agama, melainkan terdapat pula dalam bidang politik, sosial, budaya maupun ekonomi.

\subsubsection{Fundamentalisme Islam}

Sebagai fenomena yang hadir dalam sejarah dan pergulatan sosial-politik, fundamentalisme mempunyai latar belakang yang beragam, baik latarbelakang teologis maupun politis. Bahkan fundamentalisme tidak lahir dari rahim agama tertentu, tapi merupakan fenomena agama-agama pada umumnya. Apalagi bila agama tertentu mempunyai potensi dan obsesi politis. Belakangan ini, di Indonesia, fundamentalisme merupakan topik yang kerap diperbincangkan bukan sebagai bahan diskusi atau wacana belaka, melainkan artikulasi politik. Mencuatnya keinginan masyarakat muslim di Indonesia untuk menerapkan syariat Islam merupakan salah satu proposal yang mengindikasikan lahirnya fundamentalisme dalam bentuknya yang bersifat politis. ${ }^{22}$

Fenomena fundamentalisme muncul dari keberagaman "penafsiran atas teks" Kitab Suci. Hamid Abu Zayd menyebut fenomena ini sebagai karakteristik dari "peradaban teks", sehingga membentuk masyarakat yang sangat menghargai teks. Dari penghayatan terhadap teks, fundamentalisme Islam dapat diklasifikasikan dalam tiga tipe. ${ }^{23}$

1. Fundamentalisme liberal. Para penganut kategori ini melihat doktrin keagamaan secara literal dan tekstual. Apa yang disampaikan teks dipahami dan diterima secara hurufiah, tanpa proses penghayatan secara sosiologis dan antropologis. Tipe ini merupakan kecenderungan umum dari fundamentalisme Islam. Akibat dari perhatian terhadap teks, membentuk kesadaran teosentris, yaitu bahwa pandangan kegamaan mereka dianggap satu-satunya yang merujuk kepada Tuhan, sedangkan pandangan yang lain tidak. Konsekuensinya, atas nama Tuhan mereka menolak perbedaan dan keragaman pandangan. Kelompok ini menggunakan alQur'an sebagai simbol otoritas. 'Kembali kepada al-Qur'an dan Sunnah (al- 'awdah ila alQur'an al-Sunnah) digunakan sebagai "teologi" yang akan mengukuhkan Tuhan. ${ }^{24}$ Dari sini nampak jelas bahwa kalangan fundamentalis menafikan pandangan al-Qur'an yang sebenarnya terhadap pluralitas. Inilah yang sering berhembus saat ini di tanah air. Hal ini juga menyebabkan munculnya distingsi antara hal-hal yang bersifat teosentris dengan hal-hal yang bersifat sosio-antroposentris.

2. Fundamentalisme moderat. Hal ini sering disebut sebagai lokus paradoks fundamentalisme. Bahwa fundamentalisme dianggap sebagai perlawanan terhadap modernitas, tidaklah benar. Sebaliknya justru modernitas diakrabi oleh mereka yang menganut fundamentalis. Di Indonesia penganut fundamentalisme ini adalah mereka yang mengenyam pendidikan di

\footnotetext{
22 Zuhairi Misrawi, Op. Cit., hlm. xviii.

${ }^{23}$ Ibid., hlm. xxix.

${ }^{24}$ Ibid., hlm. xxv.
} 
kampus-kampus umum (non-agama). Kaum fundamentalis moderat berpandangan bahwa agama adalah dogma yang bersifat praktis. Agama tidak perlu diinterpretasikan dan didiskusikan. Apa yang datang dari agamawan mesti diyakini sebagai sebuah kebenaran absolut. Dalam pandangan yang lebih konservatif, bahwa keberagamaan seseorang diukur secara simbolik. Yaitu, selama seseorang menggunakan simbol-simbol keagamaan dan melaksanakan ritual-ritualnya, maka keberagamaan orang tersebut dianggap benar. Tatkala berhadapan dengan doktrin, sikap yang muncul adalah tunduk dan patuh.

3. Fundamentalisme radikal. Golongan ini merupakan kelompok yang banyak disoroti dewasa ini. Bila kelompok pertama dan kedua cenderung bersifat lunak, kelompok ketiga ini sering menggunakan pemaksaan dan kekerasan sebagai alternatif untuk mencapai tujuan mereka. Mereka lebih dikenal sebagai kelompok radikal. Dalam menjalankan misinya, kelompok radikal mempunyai kecenderungan menolak, mengganti sistem dan membenarkan kekerasan. Pemikiran yang dijadikan landasan adalah "klaim mayoritas". Mayoritas umat Islam di Tanah Air dijadikan landasan untuk mendesak pandangan mereka untuk menerapkan hukum Islam (syariat). ${ }^{25}$

Ketiga tipologi di atas mempunyai kemiripan pandangan, hanya saja yang membedakan antara satu dengan yang lain adalah cara yang digunakan dalam mengegolkan ambisinya. Kemiripan tersebut secara ringkas dapat dilihat dalam beberapa hal berikut. ${ }^{26}$

a. Anti Pluralisme. Kalangan fundamentalis Islam meyakini bahwa apa yang mereka persepsikan tentang Islam adalah yang paling benar, sedangkan yang lain adalah salah. Karena itu, mereka menolak pluralisme dan menggantikannya dengan kekafahan (kesempurnaan) Islam, sementara pluralisme merupakan bentuk pelecehan terhadap agama dan penyesatan yang merongrong akidah (keyakinan pokok) umat. Padahal al-Qur'an dalam ayat lain memberikan apresiasi terhadap pluralitas, baik secara substantif maupun secara simbolik. Pluralitas adalah sunnah Tuhan (QS 10:99). Al-Quran juga menggariskan bahwa Tuhan menciptakan agama sebagai jalan, dan jalan tersebut bersifat pluralitas (QS $5: 48) .{ }^{27}$

b. Anti HAM. Dalam hal HAM kelompok ini menganggap bahwa hukum Tuhan yang secara literal disebutkan dalam teks-teks keagamaan adalah yang paling benar. Sedangkan hukum manusia, seperti HAM, dianggap sebagai hukum jhiliyah. Karena itu, menurut mereka, HAM secara jelas bertentangan dengan Islam.

c. Anti Demokrasi. Demokrasi di kalangan umat Islam menjadi perselisihan karena kaum fundamentalis secara tegas menganggap demokrasi bertentangan dengan Islam. Demokrasi adalah hukum kerakyatan, hukum manusia, sedangkan Islam adalah hukum Tuhan. Bahkan menurut mereka, Islam sudah sangat sempurna dengan konsepsi syura-nya. Demokrasi menurut kaum fundamentalis merupakan salah satu bentuk pengingkaran terhadap Tuhan. ${ }^{28}$ Selain itu, demokrasi ditolak oleh kaum fundamentalis juga karena demokrasi adalah produk negara-negara Barat yang beragama Kristen yang berpaling dari Syariat hukum Islam.

\footnotetext{
25 Ibid., hlm. xxxii.

${ }^{26}$ Ibid., hlm. xxxiii.

${ }^{27}$ Ibid., hlm. xxxv.

${ }^{28}$ Ibid., hlm. xxxvii
} 
Selain itu, tuntutan penegaraan syariat Islam juga diwarnai oleh aktivitas-aktivitas gerakan radikal seperti FPI (Front Pembela Islam), FKASWJ (Forum Komunikasi Ahlu Sunnah Waljamaah), HTI (Hibut Tahrir Indonesia), MMI (Majelis Mujahidin Indonesia), KISDI (Komite Indonesia untuk Solidaritas Dunia Islam), HIPPMI (Himpunan Mahasiswa Antar Kampus), DDII (Dewan Dakwah Islamiyah Indonesia), GPI (Gerakan Pemuda Islam), Laskar Jihad, dan yang masih hangat adalah "Garis" (Gerakan Reformis Islam) yang bereaksi terhadap pengumuman hasil Pilpres 22 Mei 2019. Kelompok ini dilihat sebagai kelompok fundamentalis radikal, karena sering menggunakan kekerasan dalam memaksakan pandangan atau kehendak mereka.

\subsubsection{Fundamentalisme Kristen}

Dalam konteks dialog antarumat beragama, khususnya dalam hubungan dengan fundamentalisme Islam, kiranya perlu dilihat juga fundamentalisme dalam agama Kristiani. Fundamentalisme meskipun mengklaim diri sebagai sebuah gerakan pemurnian ajaran atau kembali ke masa awal, ia adalah sebuah gerakan modern. Pemikiran tentang fundamentalisme baru mulai muncul ketika gereja sudah mapan di dalam Gereja Katolik Roma, yang memegang monopoli ajaran di abad pertengahan Eropa. Akar dari fundamentalisme Kristen sendiri bisa dirunut mulai dari awal Reformasi, walaupun Martin Luther maupun John Calvin sendiri sulit untuk dimasukkan ke dalam kategori fundamentalis, jika kita memakai ukuran masa kini.

Hal yang menjadi akar bagi fundamentalis yang dirintis gerakan Reformasi, seperti yang sudah disinggung di atas, adalah tiga prinsip: sola gratia, sola fides, sola scriptura (hanya rahmat, hanya iman, hanya Kitab Suci). Secara ringkas dapat dijelaskan sebagai berikut. Sola gratia berarti keselamatan hanya dapat datang dari Tuhan sebagai rahmat dan pemberian cuma-cuma. Ia tidak harus diperoleh dengan mengumpulkan kebajikan atau pahala. Sola fides berarti keselamatan yang merupakan rahmat hanya dapat diperoleh dengan pengakuan iman kepada Yesus Sang Juru Selamat. Ia menjadi satu-satunya jalan mencapai keselamatan. Sola scriptura berarti hanya Kitab Suci yang menjadi petunjuk manusia menuju Allah, dan dengan ini berarti seluruh hukum gereja tidak berlaku. Semua orang berhak melihat apa yang Tuhan inginkan melalui Kitab Suci, tanpa perantaraan imam atau gereja. Ajaran ini juga sering disebut sebagai imamat seluruh umat beriman (priesthood of all believers). Dengan demikian setiap umat beriman boleh membaca dan menafsirkan Kitab Suci, tanpa tergantung pada ajaran resmi. Tuhan menyapa setiap orang melalui Kitab Suci. Konsekuensi dari kebebasan umat menafsirkan Kitab Suci tanpa kendali adalah munculnya berbagai denominasi di kalangan Kristen Reformasi dewasa ini.

Kesemua prinsip di atas adalah reaksi atas monopoli ajaran Gereja Katolik Roma. Mereka lahir dalam sebuah konteks. Imamat seluruh umat beriman misalnya adalah sebuah reaksi atas bobroknya kekuasaan para imam di zaman itu. Luther setelah melakukan penyelidikan di dalam Kitab Suci menemukan bahwa banyak praktik gereja di saat itu bertentangan dengan Kitab Suci. Ia pun menerjemahkan Alkitab ke dalam bahasa yang bisa dibaca awam, yaitu bahasa Jerman, karena Alkitab di waktu itu hanya tersedia dalam bahasa Latin dan Yunani yang tidak dimengerti orang biasa (meskipun belum banyak orang yang bisa membaca di waktu itu).

Akar kedua dari fundamentalisme adalah gerakan revivalisme di Eropa. Aliran-aliran baru yang muncul dari revivalisme ini adalah Anabaptisme, Puritanisme, Pietisme, dan Metodism yang lahir kurang lebih mulai dari abad ke-16 sampai 18. Kesemua gerakan ini lahir sebagai reaksi atas makin bergesernya Gereja Protestan ke arah kependetaan, upacara sakramen, dan semakin duniawi sehingga mereka melihatnya semacam arah kembali ke Katolik. Puritanisme Inggris misalnya lahir sebagai reaksi atas Gereja Inggris (Anglikan) yang mereka lihat masih memegang ritualisme dan 
sakramentalisme, dan semakin menyamai kepausan. Mereka lalu sewaktu hijrah ke tanah baru Amerika mempraktikan agama Kristen sesuai dengan versi mereka.

Di Amerika fundamentalisme muncul sebagai gerakan keagamaan yang timbul di lingkungan Protestan pada tahun 1920 -an. ${ }^{29}$ Beberapa pokok pikiran penting yang mendasari gerakan tersebut:

Pertama, Kitab Suci mengandung kebenaran absolut yang tak terbantahkan dan tidak bisa direvisi oleh pendekatan hermeneutis modern sekalipun. Teologi dan ilmu pengetahuan dan interpretasi rasional menjadi relevan sejauh tidak bertentangan dengan kebenaran dalam Kitab Suci.

Kedua, orang yang mengambil posisi fundamentalistis adalah orang Kristen sejati, selebihnya harus ditobatkan.

Ketiga, isi iman yang absolut benar harus ditegakkan secara politis dan mengikat semua warga negara dan oleh karena itu prinsip pemisahan atara Gereja dan negara harus ditolak. ${ }^{30}$ Kemudian pada sekitar tahun 1970-an diperluas ke kelompok-kelompok lain. ${ }^{31}$

\subsection{Kekatolikan dan Fundamentalisme}

Meninjau "kekatolikan" dalam konteks pembicaraan tentang fundamentalisme seperti yang ditulis oleh F.O’Meara yang dikutip dalam Stephen B. Bevans merupakan kutub lawan dari kekatolikan. Fundamentalisme merupakan ancaman yang paling serius bagi kekatolikan dan juga bagi kekristenan sejati di seluruh dunia. ${ }^{32}$

Kekatolikan sesuai dengan asal kata/namanya kath'holon, yang berarti "menyangkut keseluruhan", mengandung makna umum, terbuka kepada siapa saja, untuk segala bangsa dan segala zaman. Sebutan Kekatolikan juga menegaskan siapa pusat imannya, yaitu Kristus yang mewartakan Allah sebagai yang mengasihi semua orang, dan dalam Kristus Allah menghendaki semua orang memperoleh keselamatan. Pengertian Kekatolikan tentang sejarah juga menentang setiap penggunaan atau tafsiran picik atas sebuah teks atau tradisi.

Kekatolikan yang terbaik sama sekali tidak sektarian, tetapi inklusif, terbuka, bertenggang terhadap pelbagai perspektif dan teologi. Sikap Gereja Katolik ini ditegaskan dalam Dekrit Nostra Aetate:

Gereja Katolik tidak menolak apa pun, yang dalam agama-agama itu serba benar dan suci. ... Maka, Gereja mendorong para putranya supaya dengan bijaksana dan penuh kasih, melalui dialog dan kerja sama dengan para penganut agama-agama lain, sambil memberikan kesaksian tentang iman serta peri hidup

Kristiani, mengakui, memelihara, dan mengembangkan harta kekayaan rohani dan moral serta nilai-nilai sosio-budaya, yang terdapat pada mereka. ${ }^{33}$

Paus Yohanes Paulus II, dalam berbagai imbauan aposolik setelah sinode regional menjelang berakhinya milenium kedua, juga mewanti-wanti tentang semakin kuatnya pengaruh kelompok-

${ }^{29}$ Matias Daven, Arus balik: Gerakan Fundamentalis dalam Islam, dalam Jurnal Ledalero, Vol. 13, No.2 Desember 2014, hlm. 274.

${ }^{30}$ Ibid.

${ }^{31}$ Jacobs, Op. Cit. hlm. 261.

${ }^{32}$ Stephen B. Bevans, Op. Cit., hlm. 278.

${ }^{33}$ Dekrit Nostra Aetate dari Konsili Vatikan II no. 2. 
kelompok fundamentalis. Dalam Ecclesia in Ocenia (EiO) misalnya, beliau mengakui bahwa "di beberapa wilayah misi, para uskup prihatin atas dampak yang dimiliki kelompok-kelompok atau sekte-sekte keagamaan ini atas jemaat katolik" (EiO 24; jugaEiAf 66; EiE 16 EiA 73). ${ }^{34}$

\section{PENUTUP}

Indonesia merupakan negara yang pluralistis. Pluralisme merupakan kekayaan bangsa, yang bila dirajut secara baik menampilkan kekhasan sekaligus kekayaan bangsa dan negara. Namun apabila pluralisme tidak dikelola secara baik, ia akan mendatangkan petaka bagi bangsa dan negara.

Dalam artikel ini hanya disinggung mengenai fundamentalisme Islam dan fundamentalisme Kristiani. Namun sesungguhnya fundamentalisme hidup dalam setiap kelompok umat beragama. Islam dibicarakan sehubungan klaim mayoritas yang sering menimbulkan kecemasan di kalangan minoritas dan mengancam pluralisme religius. Doktrin yang mengemuka antara lain, "menegakkan syariat islam" (tatbiq al-syariah), "mendirikan negara islam" (al-khilafah alislamiyah), "Islam kompatabel untuk setiap ruang dan waktu" (al-islam shalihun likulli zamanin wa makanin), ${ }^{35}$ dan lain-lain.

Sedangkan Kristen disinggung mewakili kelompok minoritas yang sering hidup di bawah kecemasan disebabkan acaman mayoritas. Kendati kecemasan terhadap fundamentalisme mayoritas, Indonesia merupakan negara yang memiliki Pancasila sebagai dasar negara. Dasar negara ini yang membendung kemungkinan fundamentalisme atau dominasi mayoritas terhadap minoritas serta menjamin pluralisme religius. Setidaknya dengan dasar negara Pancasila, setiap kelompok agama diimbau agar dalam menjalankan agamanya tidak saja mengagungkan Tuhan (matra vertikal), melainkan juga mempunyai perhatian terhadap masalah kemanusiaan (matra horizontal). Di sini sebisa mungkin agama didorong untuk menjadi lokomotif pembebasan manusia dari segala belenggu dan penindasan yang timbul dari sesama umat beragama, demi tetap tegaknya Negara Kesatuan Republik Indonesia (NKRI).

\section{Daftar Kepustakaan}

\section{Dokumen Gereja}

Konsili Vatikan II, Dekrit Nostra Aetate.

\section{Kamus}

Depdiknas, Kamus Besar Bahasa Indonesia, Edisi Ketiga, Cetakan Kedua, Jakarta: Balai Pustaka. 2002.

\footnotetext{
${ }^{34}$ Stephen B. Bevans, Op. Cit., hlm. 278.

${ }^{35}$ Zuhairi Misrawi, Op. Cit., hlm. xix.
} 


\section{$\underline{\text { Buku-Buku }}$}

Atawolo, Andreas Bernadinus. Dialog Antarumat Beragma, Kerjasama Membangun Karajan Allah, Telaah Kritris Pemikiran Jacques Dupuis. Yogyakarta: Yayasan Pustaka Nusatama.

Bevans, Stephen B. Teologi dalam Perspektif Global, sebuah Pengantar. Maumere: Penerbit Ledalero, 2010: 279.

Daven, Matias. Arus balik: Gerakan Fundamentalis dalam Islam, dalam Jurnal Ledalero, Vol. 13, No.2 Desember 2014, hlm. 263-294.

Hendropuspito, D. Sosiologi Agama. Yogyakarta: Kanisius-BPK Gunung Mulia, 1983.

Jacobs, Tom. Paham Allah, dalam Filsafat, Agama-Agama, dan Teologi. Yogyakarta: Kanisius, 2002.

Lindholm, Tore, Cs. Kebebasan Beragama atau Berkeyakinan: Sebepara Jauh? Sebuah Referensi tentang Prinsip-Prinsip dan Praktek. Rafael Edy Bosko dan M. Rifa'i Abduh (Penerj.). Yogyakarta: Kanisius.

Nuad, Ismatillah A. Fundamentalisme Progresif, era baru dunia Islam. Jakarta: Penerbit Panta Rei, 2005.

Misrawi, Zuhairi dalam Ismatillah A Nuad, Fundamentalisme Progresif, era baru dunia Islam. Jakarta; Penerbit Panta Rei, 2005.

Suharyo, I. The Catolic Way Kekatolikan dan Keinndonesiaan Kita. Yogyakarta: Kanisius, 2009.

\section{Website/Internet}

Amir Mugozin, https://medium.com/@ mugozin76/fenomena-fundamentalisme-dan-radikalisme, Diakses 15 April 2019.

Ferry Novrika. https://jalandamai.org/asal-usul-fundamentalisme-terorisme-radikalisme-bag1.html, Diakses 15 April 2019. 